Article

\title{
Assessing Resilience to Energy Poverty in Europe through a Multi-Criteria Analysis Framework
}

\author{
Apostolos Arsenopoulos ${ }^{1, * \mathbb{D}}$, Vangelis Marinakis ${ }^{2}$, Konstantinos Koasidis ${ }^{1}{ }^{1}$, \\ Andriana Stavrakaki ${ }^{1}$ and John Psarras ${ }^{1}$ \\ 1 Institute of Communication and Computer Systems, 15773 Athens, Greece; kkoasidis@epu.ntua.gr (K.K.); \\ astavrakaki@epu.ntua.gr (A.S.); john@epu.ntua.gr (J.P.) \\ 2 Institute for European Energy and Climate Policy, 1043GR Amsterdam, The Netherlands; \\ vmarinakis@ieecp.org \\ * Correspondence: aarsenop@epu.ntua.gr; Tel.: +30-210-772-3760; Fax: +30-210-772-3550
}

Received: 27 May 2020; Accepted: 9 June 2020; Published: 16 June 2020

\begin{abstract}
This study introduces a framework for assessing the resilience of different European countries against the problem of energy poverty. The proposed framework is established upon two major implementation pillars: capturing stakeholder knowledge and employing a multi-criteria analysis framework in order to provide valuable insights and objective results. The implicated evaluation criteria have been identified by the group of stakeholders and incorporate several socio-economic aspects of the problem beyond the energy dimension. The proposed methodology is largely dependent on the engaged stakeholders' assessments, thus introducing nuggets of subjectivity into the whole analysis. However, it significantly differs from other energy poverty-based approaches, its novelty lying in that it directly attempts to evaluate a country according to its potential to deal with the problem as a whole, rather than deconstructing it in components and partial indicators. The proposed framework is demonstrated in countries in both Southern/Eastern and Northern/Western Europe (Austria, Belgium, Croatia, France, Greece, Ireland, Italy, Latvia, the Netherlands, Romania, Spain), exploiting diversities and particularities associated with their context.
\end{abstract}

Keywords: energy poverty; resilience; comparative analysis; multi-criteria analysis; TOPSIS

\section{Introduction}

The pursuit of a transition towards a sustainable and resilient energy sector has set in the spotlight and laid the groundwork for three major transformations focused on climate change, security of supply and energy poverty [1]. With regard to the first two, they appear to have drawn significant attention in the literature throughout the years [2,3], since there are a multitude of related studies and analyses revolving around climate issues of mitigation and adaptation, as well as policy making in several economic sectors where greenhouse gas (GHG) emission reduction is considered among the main evaluation pillars [4-6]. However, less attention has been paid to the third axis, even though it has a great influence on the lives of millions of people worldwide.

The notion of energy poverty was established upon the inability of households to access and maintain adequate levels of domestic energy services, such as electricity, gas, heating, cooling, etc., at an affordable cost [7]. According to the International Energy Agency (IEA), it is estimated that 940 million people worldwide lack access to electricity ( $13 \%$ of the world's population), while 3 billion are deprived of clean fuel for cooking ( $40 \%$ of the world's population), two core pillars that current energy poverty definitions have been established upon, which come to confirm the severity of the problem [8]. Energy poverty is also extended to severe known impacts on the health of citizens, including mental health issues, respiratory, and circulatory problems [9]. Thomson et al. (2017) also attempted to provide an 
in-depth analysis of the connection between energy poverty and health, with the findings highlighting that energy-poor households are significantly more affected by health issues than non-energy-poor households [10].

The current situation in the European Union (EU) regarding the energy poverty levels, based on data obtained from EU Energy Poverty Observatory (EPOV), indicates that the estimated number of energy-poor households exceeds 50 million [11], which translates to more than 100 million EU citizens, considering the average size of a European household [12]. In this context, Bouzarovski and Petrova (2015) highlighted the variability of energy poverty spanning across Europe, with Southern and Eastern Europe suffering the most as a result of a mix between low-income economies, non-efficient housing and high energy prices [13]. On the contrary, countries located in Northern and Western Europe feature lower levels of energy poverty, stemming, among others, from their higher gross domestic product (GDP) per capita and the financial support provided to those of the lowest income quantiles $[14,15]$.

Although the number of countries that recognise energy poverty formally in legislation or policy is rising, in the majority of EU member states it lacks formal definition. The absence of a concise definition to gather under a common conceptual umbrella the main notions of the problem, i.e., energy and income, has inflated the impacts of the phenomenon [9]. Significant effort has revolved around identifying the necessary measures and policies to effectively mitigate the phenomenon. In this respect, the European Commission (EC) has laid emphasis on enhancing consumer protection and relieving energy-poor consumers since the second Clean energy for all Europeans package [16,17]. The revised third energy package $[18,19]$ built on this issue as part of an ambitious European strategy towards 2030 and 2050, highlighting the concept of energy poverty and encouraging each member state to deal with this issue based on their context-specific socio-economic conditions as well as their needs and priorities at both the national and European level [20,21]. Under the new Governance Regulation, member states are required, in their national energy and climate plans (NECPs), to assess the number of households in energy poverty and introduce an objective, as well as indicative policies and measures to reduce it.

Part of the NECP adopted by member states attempts to point the attention of policy makers and all relevant stakeholders to the explicit need for developing more tangible ambitions to ensure the transition towards a socially more fair and climate-resilient housing sector [22]. However, the current provision for energy poverty leaves little room for addressing the grassroots of the problem as well as implementing social policy measures to relieve those affected. On the other hand, the lack of a single comprehensive and integrated policy for reaching the bottom of the problem leads to piecemeal approaches, which in turn seem to trigger the development of a more consolidated suite of tools and frameworks to monitor energy poverty, including a focus on dimensions that have received little attention to date, such as the social impact (e.g., employment rate, GDP, etc.), thus bringing to the foreground the key question regarding the level of readiness for each EU country to deal with and alleviate energy poverty.

Drawing from the abovementioned, and given the multifaceted nature of energy poverty, the importance of integrating different evaluation frameworks to capture a more comprehensive context of the required transformation emerges as a crucial factor $[23,24]$. In this context, this paper aims to assess the resilience to energy poverty of selected European countries through a multi-criteria analysis framework. From a methodological point of view, this paper contributes to the literature by demonstrating how (i) a bottom-up multi-criteria analysis framework and (ii) a qualitative semi-structured stakeholder-based driven framework can be integrated into a co-production process with stakeholders of a large variety to support policymakers in designing optimal energy poverty alleviation pathways. The employed multiple-criteria decision analysis (MCDA) framework is commonly used in the literature for the evaluation of climate policies as well as technological potentials and parameters [4], although to the best of our knowledge this is the first paper to lay focus on the resilience of several EU countries against the ever-growing problem of energy poverty. A diverse set of European countries are evaluated and ranked, considering the stakeholders' preferences and the latest criteria data in both Southern/Eastern and Northern/Western Europe (Austria, Belgium, Croatia, 
France, Greece, Ireland, Italy, Latvia, the Netherlands, Romania, Spain), as different regions present varying barriers to energy poverty mitigation [25]. This research work can provide valuable insight to potential stakeholders on the degree of readiness of different countries in tackling energy poverty.

The rest of the paper is organized as follows: In Section 2, the country context studies are presented. In Section 3, the proposed methodological framework is analysed, while in Section 4 the application of the model's results is presented. In Section 5, the conclusions of the current study are discussed.

\section{Energy Poverty Status Quo}

This section summarises country-specific information on contextual factors (Austria, Belgium, Croatia, France, Greece, Ireland, Italy, Latvia, the Netherlands, Romania, Spain) relevant to energy poverty, clustered in climate, population and demographics, the economy, the residential building stock, energy market and relevant energy efficiency policies.

\subsection{Climate, Demographics and Economy}

Austria can be classified as a country of temperate climate [26], although several differences among regions exist [27]. As of 2018, the population of Austria was estimated at 8.83 million people, showing an increase of almost $10 \%$ since 2000, which is expected to continue [28]. On the fiscal axis, Statistik Austria (2019) indicates that the economy of Austria has grown significantly in 2018 [28].

Belgium features a temperate maritime climate [29] and has an ever-growing population, currently estimated at 11.4 million people. [30,31]. The economy of Belgium is considered to be strong since it is well-diversified [32], mainly driven by transport, services and manufacturing [33].

Croatia's climate varies from Mediterranean, continental and sub-alpine [34]. The population of Croatia has been estimated at nearly 4.28 million people, according to the 2011 census, while projections show a negative population growth rate in the upcoming years [31]. The economic recession triggered a trend of outward migration of the working population and lower birth rate because of the predominantly poor economic conditions [35].

Due to its large area $\left(640,000 \mathrm{~km}^{2}\right)$, France experiences a temperate oceanic climate [36] with its western part being influenced by the Atlantic Ocean, while its southeastern end has a Mediterranean climate, and regions above a 600- to 800-metre altitude feature an alpine climate. The country's population was almost 67 million people as of 2019, showing a positive growth rate [37]. The French economy has demonstrated significant growth rates for both the GDP and employment rates in the recent years [38].

The special geographical features, combined with a total population of 10.8 million (2011 census), have led to increased rates of urbanisation, leaving part of Greece barely inhabited. Greece's population rate featured a declining trend during the last decade. Greece was severely affected by the economic crisis of 2008 and the austerity period that proceeded [39], which also triggered a major drop in the employment rate [40,41].

Ireland has a mild, temperate climate [42]. The population of the country is estimated at 4.8 million according to the 2016 census. Since the crash due to the economic crisis of 2008, a robust programme of economic retrenchment and long-term political stability in Ireland has borne the burden of the slow but steady reforms needed in the national economy, coupled with increased employment rates. However, one of the main features of Ireland that has remained intact is the chronic shortage of affordable accommodation to rent or buy as an aftermath of the crisis, along with a cessation of house building [43].

Italy has an extensive coastline and a predominantly hilly terrain with some mountainous and lowland areas [44,45]. The Italian population was estimated at more than 60.36 million in 2018 . The Italian economy is static, driven by export and household consumption. Latitude variance has an impact not only on climate, but also economy-wise, since the average income fluctuates significantly amongst the different regions causing long-term inequalities [46]. 
The climate of Latvia ranges from maritime to continental and is rather moist humid due to the Atlantic Ocean and the Baltic Sea [47]. The population of the country is 1.9 million households, with projections showing a continuing negative population growth rate [37]. The economy of Latvia is relatively weak compared to other EU countries, despite a high employment rate, which is driven by low productivity [48] which subsequently leads to low average income compared to other countries in the EU [49].

The Netherlands' climate is considered temperate with mild winters and cool summers due to ocean currents [50], and since it is influenced by the North Sea and the Atlantic Ocean, it has a cool, cloudy and humid environment for most of the year. The Netherlands is considered highly densely populated [51], since 17.4 million people live in an area of $41,800 \mathrm{~km}^{2}$. The Netherlands has a strong economy [52] which is extremely robust, showing a high GDP per capita and low unemployment.

The climate of Romania is humid temperate-continental, characterised by cold winters and hot summers [53]. The population of the country is almost 20 million people. The country has experienced a population decrease in recent years due to migration and demographic decline in parallel with the aging of the population. The Romanian economy is relatively strong, based mainly on industry and services, and has had a sustained growth since the 2008 economic crisis.

Spain has different climate zones due to its geographical situation and orography conditions [54]. The country has a population of around 47 million. The economic recession of 2008 largely affected the economy of Spain with the employment rates still remaining below 70\% as of 2018 [40], although there are signs of improvement of the country's economy in recent years [38]. As a result of the crisis, unemployment has played a major role in the deteriorating energy poverty [55].

\subsection{Residential Building Stock and Energy Market}

It is estimated that about $60 \%$ of the apartments in Austria were built before 1980 thus lack proper insulation and feature high energy consumption. Buildings built after 1990 are expected to be significantly better insulated. Overall, existing buildings have benefited from improvements in insulation (i.e., $2 \%$ of the existing buildings are renovated each year). Approximately $78.5 \%$ of the energy consumed in private homes is used for heating purposes, with the most common source being wood, featuring a share of about $30.4 \%$, followed by gas at $29.4 \%$ and oil at $18.4 \%$ [28].

$75 \%$ of all residential buildings in Belgium were built before 1982 and therefore before thermal regulations. $24 \%$ of all homes were built before 1919 and 36\% before 1945, therefore a significant percentage of the building stock is relatively old [56]. Belgian households feature high energy usage, mainly due to the interaction between high energy consumption for space heating [57] and the old building stock, which inevitably leads to a high share of natural gas (47\%) and oil (38\%) consumption [58].

The building stock of Croatia currently includes approximately two million dwellings/units, $63 \%$ of which were built before 1980 and half of them even before 1970 [59]. A large proportion of buildings underlies a significant thermal deficit. The ongoing economic recession, combined with the high biomass potential of the region [60], lead to the usage of firewood and all relevant fuel types as a favourable option for households to cover their energy needs [61], creating business models that could also alleviate energy poverty in the region [62].

In France, the renovation target is considered crucial, since almost $58 \%$ of the domestic building stock was constructed before 1980 [63] without significant thermal specifications, given the introduction of thermal regulations in 1974. Household energy consumption in France is dominated by electricity and natural gas, each with a $32 \%$ share of the total consumption, followed by fuel oil at $10 \%$ [64].

Greece has approximately 6.86 million residential dwellings, almost half of which are dwellings without sufficient thermal insulation since they were built before 1980 [63]. Greek households have high energy usage due to the old building stock that leads to increased energy consumption for space heating [65]. These needs are mostly covered by oil and petroleum products, constituting almost $50 \%$ of the total consumption, followed by electricity at almost 30\% [58]. 
The housing stock in Ireland is relatively old with almost half (45\%) of the dwellings built before 1980 and just $2 \%$ built since 2011 [66]. This situation is exacerbated by the relatively late introduction of building regulations in Ireland. The residential energy mix in 2018 was mainly dominated by fossil fuels like oil and petroleum products, natural gas, or even solid fuels to cover the necessary energy needs [67].

Italy has 31.96 million dwellings, most of which were built before $1945(16 \%)$, while $70 \%$ of all dwellings/units were built before 1980 [63]. Thermal regulations for residential buildings were introduced in 1991, as a result of the difficulties in defining clear building and technical standards that can be adapted to the diverse conditions caused by the differences between climate zones. Natural gas represents half of the fuels used in the residential sector [58], since $98 \%$ of the households have some form of heating system [68] which is a key indicator of the impact winter has on Italian society.

In Latvia, the total number of dwellings or units is 1.04 million. Only $10-15 \%$ of all residential buildings in Latvia have been built over the last 10 to 15 years and are considered to be modern and well-established dwellings [63]. The increased space heating needs are covered mainly by biomass. The three main sources of heat are solid biomass $(41.5 \%)$, district heating $(30.5 \%)$ and natural gas $(8.9 \%)$, while district heating is also largely dependent on the use of biomass $(61.2 \%)$ and natural gas $(37.6 \%)$ as fuel for heat-only boilers [69].

In the Netherlands, although gradually decreasing, the share of dwellings built before 1980, generally considered as less energy efficient, is still about two-thirds of the total building stock. The Dutch energy system is heavily dependent on fossil fuels [70], with natural gas being the primary energy source making up to $41 \%$ of the total energy consumption, the vast majority of which goes to heating dwellings [71]. A major transformation of 1.5 million houses is envisaged by 2030, leading to natural gas being phased out by the residential sector in a cost-effective manner by 2050 [72,73].

The number of dwellings in Romania has increased in recent years [74], therefore complying to the new regulations and technical rules. There is a high percentage of home ownership [75], whilst the most frequent issues experienced being damaged window frames and leaks [76]. 70\% of all dwellings in Romania were built before 1980 and therefore before thermal regulations were applied. Because of the cold winters, most of the energy consumed in the residential sector is used for space heating purposes, deriving mainly from firewood and biomass [77] and accounting for almost $40 \%$, followed by natural gas at $31 \%$.

There are 26.56 million dwellings or units in Spain. $43 \%$ of all dwellings or units were built before 1980, before the enactment of the first laws to include insulation requirements for buildings [78,79]. Final energy consumption in the Spanish residential sector amounts to 15.227 ktoe, derived largely from electricity $(40 \%)$, gas $(25 \%)$, renewable energy $(18 \%)$ and oil products $(17 \%)$ [80]. Energy consumption per dwelling in Spain is relatively small, principally due to moderate climate conditions. Space heating and water heating needs are smaller in comparison to the rest of Europe.

\subsection{Energy Poverty, Energy Efficiency Policies and Obligation Schemes}

The national statistics office produces a report on energy poverty every second year along with a report about energy consumption of Austrian households. Even though there is no official definition of energy poverty, different approaches have been developed and are currently in use [81]. There are a multitude of regulations in Austrian legislation regarding energy poverty. Only one is driven by the requirements of Article 7 of the Energy Efficiency Directive (EED), coupling energy poverty with energy efficiency as part of the Federal Energy Efficiency Act, upon the claim that energy savings can be counted as 50\% higher if they stem from households that belong to a low-income quintile.

To assess the level of energy poverty in Belgium, the King Baudouin Foundation [82] utilised three key indicators closely correlated with income, concluding that $21 \%$ of the domestic population suffered from at least one form of energy poverty. The National energy and Climate Plan in 2018 raised the problem of energy poverty as a policy issue, incorporating a diverse set of measures for addressing it, at both the federal and regional level. Due to the decentralised decision-making model in Belgium, 
there is a lack of a universal energy efficiency obligation scheme (EEOS), but alternative measures have been introduced by the regions instead.

Even though Croatia lacks an official energy poverty definition, national legislation defines vulnerable consumers as in need of special protection. Energy poverty in Croatia is addressed primarily through direct financial assistance from public social care services, local and national authorities that deal with the problem for low-income households. Although almost 10\% of the population fail to keep their home adequately warm, only $3 \%$ are beneficiaries of such aid [83]. Article 7 has been recently adopted in the legislation under the Energy Efficiency Law in 2018 and the Rulebook on the Energy Efficiency Obligation System in 2019.

Legislation activity helped France identify the issue of energy poverty, introducing as of 2010 the legal definition of fuel poverty regarding the capability of a household to acquire the necessary energy supply to meet basic needs. Identifying a fuel-poor household is based on three metrics combining financial criteria with surveyed discomfort levels. $11.6 \%$ required more than $8 \%$ of their income to cover their energy need, while 15\% declared suffering from the cold during the winter of 2017 [84]. It is noteworthy that the French state has established initiatives to mitigate energy poverty both in the form of mandatory actions, such as the obligation schemes, but also with many interconnected schemes to retrofit housing, with special assistance to low-income households, bill subsidies and loan schemes.

In Greece, the financial crisis of 2008 demonstrated that the issue of mitigating energy poverty follows as a natural challenge, since one out of three households were in arrears on their bill and one out of four failed to keep their house adequately warm [85], while research suggests that $58 \%$ of Greek households are energy-poor [86]. The Greek state has yet to officially define energy poverty, even though partial targeting is mainly achieved through the eligibility criteria of a bill subsidy. On the same axis, both legislation introducing Article 7 of the EED (the combination of obligation schemes with alternative policy) and implemented schemes for housing renovation mostly indirectly address energy poverty.

Ireland has introduced a definition focusing on the $10 \%$ metric with a different threshold to measure the severity, with research showing that $28 \%$ of Irish households experience energy poverty [87]. There are currently 370,000 households in receipt of the fuel allowance, which is a good barometer of both the scale and persistence of the problem. In adopting Article 7 of the EED, Ireland has chosen to combine an EEOS with alternative measures in order to meet the national target. Therefore, a reduced target obligation is being implemented for designated energy suppliers.

The share of energy-poor population in Italy varies between 5-20\% [88]; however, conclusive results are difficult to estimate since there is no official definition of energy poverty. The residential sector was the dominant contributor to savings in the Italian EEOS until 2012. However, a methodology change in the calculations leads to a shift towards large-scale industrial actions [89] limiting investments in the residential segment, thus further proving the lack of coherence in the efforts of the Italian state.

Even though there is no official definition of energy poverty in Latvia, the issue is currently recognised by the Ministry of Economics [90] setting a target to reduce energy poverty below the average EU rate. In 2017, the ability to keep the home adequately warm was problematic for $9.7 \%$ of all households, while this percentage increases to $22.7 \%$ for the population at risk of poverty. The EEOS covers a small number of energy suppliers; consequently, the scheme's mandatory obligation to implement energy efficiency improvement measures, both in the suppliers' operations and in their customers' activities, applies only to a small number of economic operators.

Currently, there is no official energy poverty definition in the Netherlands and the country uses a description for vulnerable customers. However, the Netherlands Environmental Assessment Agency estimates that about 900,000 households spend either a relatively large share of their income on energy costs or are at risk of being unable to afford housing costs, including energy costs [91]. Most schemes which tackle energy poverty are mostly driven by social policies mainly focusing on building renovations targeting to increase the percentage of nearly zero-energy buildings [92], especially for the rental sector. The Netherlands has chosen not to create an obligation scheme but to 
achieve the targets through alternative policies. There is no specific reference to measures concerning the mitigation of energy poverty.

Romania currently has not legislated an official energy poverty definition, opting for a description for vulnerable customers that are assisted through social tariffs and policies. It is estimated that $23 \%$ of households are affected by energy poverty [93]. Romania ranks first among EU member countries in terms of private ownership of a home, but not all owners are able to maintain their housing to adequate living standards. Romania has not opted for an EEOS but for a range of alternative policy measures to be achieved through specific energy efficiency programmes. However, an important issue concerns the 100,000 households that are not connected to the electrical grid [94], thus raising concerns about whether Romania can target and assist them.

The Spanish government legislated the National Strategy against Energy Poverty 2019-2024 in 2019 [95], defining energy poverty as a combination of the difficulty to cover basic energy needs and an insufficient income level. The number of people affected corresponds to 3.3-7.8 million people. As part of the obligation schemes, this strategy, coupled with policy efforts, tries to shed light on energy poverty, apply social measures and perform structural changes towards helping those affected.

Table 1 gathers the information described above and provides key numerical and linguistic data for the quantitative and qualitative contextual factors identified, respectively.

Table 1. Summarised context-specific information.

\begin{tabular}{ccccccccc}
\hline Data & $\begin{array}{c}\text { Average } \\
\text { Temperature } \\
\left({ }^{\circ} \mathbf{C}\right)\end{array}$ & $\begin{array}{c}\text { Population } \\
\text { Growth } \\
\text { (Per 1000 } \\
\text { Persons) }\end{array}$ & $\begin{array}{c}\text { Unemployment } \\
\mathbf{( \% )}\end{array}$ & $\begin{array}{c}\text { Purchasing } \\
\text { Power } \\
(\mathbf{\epsilon} / \text { capita) }\end{array}$ & $\begin{array}{c}\text { Political } \\
\text { Will }\end{array}$ & $\begin{array}{c}\text { Building } \\
\text { Age (\% } \\
\text { Built } \\
<\mathbf{1 9 8 0})\end{array}$ & $\begin{array}{c}\text { Adoption } \\
\text { of } \\
\text { Article 7 }\end{array}$ & $\begin{array}{c}\text { Official } \\
\text { Definition }\end{array}$ \\
\hline Austria & 6.35 & 4.1 & 4.6 & 38,600 & Absent & 60.2 & High & No \\
\hline Belgium & 9.55 & 6.1 & 5.6 & 35,100 & Moderate & 75.3 & Low & No \\
\hline Croatia & 10.90 & -7.1 & 6.6 & 19,100 & Intense & 63.0 & High & No \\
\hline France & 10.70 & 1.5 & 8.5 & 31,500 & Low & 57.8 & High & Yes \\
\hline Greece & 15.40 & -1.8 & 16.7 & 20,600 & Low & 55.4 & Moderate & No \\
\hline Ireland & 9.30 & 15.2 & 4.8 & 56,800 & High & 45.0 & Moderate & Yes \\
\hline Italy & 13.45 & -2.1 & 9.7 & 28,900 & Moderate & 72.0 & Moderate & No \\
\hline Latvia & 5.60 & -7.5 & 6.1 & 21,300 & Moderate & 69.3 & Moderate & No \\
\hline Netherlands & 9.25 & 5.9 & 3.5 & 39,100 & Low & 60.8 & Low & No \\
\hline Romania & 8.80 & -6.6 & 4 & 19,600 & Low & 70.3 & Low & No \\
\hline Spain & 13.30 & 5.9 & 14.2 & 27,700 & Moderate & 43.0 & Moderate & Yes \\
\hline
\end{tabular}

\section{The Methodological Approach}

There is a wide set of MCDA frameworks available to serve the purposes of this paper, although only a couple of them seem to draw significant attention. Nikas et al. (2018) present a detailed review of the existing MCDA frameworks [4], highlighting the most popular ones that have remained in the spotlight until recently, which are based on pairwise comparisons, i.e., PROMETHEE and ELECTRE, while distance-based approaches, such as TOPSIS (Technique for Order of Preference by Similarity to Ideal Solution), are gaining more ground of late. So far, the literature lacks MCDA applications in the energy poverty field. In this context, the TOPSIS [96] multi-criteria analysis technique was utilised as the key component of this methodological framework for gathering a multitude of stakeholders' evaluations and examining them jointly in order to extract a final ranking of several EU countries regarding their level of resilience against energy poverty. The main reason for employing TOPSIS lies in its capacity to deal with a wide range of stakeholders in the decision-making process under a quantitative modelling framework.

TOPSIS belongs to the compensatory aggregation family of methods and has undergone several extensions throughout the years [97], with the most indicative one being found in the development of Fuzzy TOPSIS [98-101]. Despite its extensions, its core principle lies in that the selected alternative 
among the respective set of alternatives comprising the MCDA problem should feature the shortest distance from the positive (ideal) solution, and at the same time the longest distance from the negative solution (non-ideal). More specifically, TOPSIS is broken down into six separate steps:

1. Formulation of the decision matrix (alternatives/criteria):

$$
\text { Decision Matrix }=\begin{array}{ccccc} 
& C_{1} & C_{2} & \ldots & C_{n} \\
A_{1} & e_{11} & e_{12} & \ldots & e_{1 n} \\
A_{2} & e_{21} & e_{22} & \ldots & e_{2 n} \\
\ldots & \ldots & \ldots & \ldots & \ldots \\
A_{m} & e_{m} & e_{m 2} & \ldots & e_{m n} \\
\hline
\end{array}
$$

where $A_{i}, i=1,2, \ldots, m$ stands for the alternatives, $C_{j}, j=1,2, \ldots, n$ stands for the evaluation criteria and $\mathrm{e}_{\mathrm{ij}}$ stands for the evaluation score of each alternative against each criterion.

2. Calculation of the normalised decision matrix $\mathrm{R}$ :

$$
r_{i j}=\frac{e_{i j}}{\sqrt{\sum_{i=1}^{m} e_{i j}^{2}}}
$$

where $\mathrm{r}_{\mathrm{ij}}$ stands for the normalised evaluation score of each alternative against each criterion in the R matrix.

3. Calculation of the weighted normalised decision matrix P:

$$
\mathrm{p}_{\mathrm{ij}}=\mathrm{w}_{\mathrm{j}_{\text {norm }}} \times \mathrm{r}_{\mathrm{ij}}
$$

where $\mathrm{p}_{\mathrm{ij}}$ stands for the weighted normalised evaluation score of each alternative against each criterion in the R matrix, $w_{j_{\text {norm }}}=\frac{w_{j}}{\sum_{j=1}^{n} w_{j}}, j=1,2, \ldots, n, \sum_{j=1}^{n} w_{j_{\text {norm }}}=1$ and $W_{j}, j=1,2, \ldots, n$ stands for the original weight vector of each criterion $C_{j}$.

4. Determination of the positive $\left(\mathrm{P}^{+}\right)$and negative ideal $\left(\mathrm{P}^{-}\right)$solutions:

$$
\begin{aligned}
& \mathrm{P}^{+}=\left(\mathrm{p}_{1}^{+}, \mathrm{p}_{2}^{+}, \ldots, \mathrm{p}_{\mathrm{n}}^{+}\right)=\left\{\left(\max \mathrm{p}_{\mathrm{ij}}, \mathrm{j} \in \mathrm{J}\right) \text { or }\left(\operatorname{minp}_{\mathrm{ij}}, \mathrm{j} \in \mathrm{J}^{\prime}\right)\right\} \\
& \mathrm{P}^{-}=\left(\mathrm{p}_{1}^{-}, \mathrm{p}_{2}^{-}, \ldots, \mathrm{p}_{\mathrm{n}}^{-}\right)=\left\{\left(\min \mathrm{p}_{\mathrm{ij}}, \mathrm{j} \in \mathrm{J}\right) \text { or }\left(\operatorname{maxp}_{\mathrm{ij}}, \mathrm{j} \in \mathrm{J}^{\prime}\right)\right\}
\end{aligned}
$$

where $\mathrm{J}$ is associated with benefit criteria and $\mathrm{J}^{\prime}$ is associated with cost criteria.

To elaborate further, when a problem features benefit criteria $(\mathrm{J})$, the maximum $\mathrm{p}_{\mathrm{ij}}$ value represents the positive ideal solution, i.e., the alternative that maximises benefit for each criterion, and the minimum $\mathrm{p}_{\mathrm{ij}}$ represents the negative ideal solution, i.e., the alternative that minimises benefit for each criterion. In a similar way, when a problem features cost criteria $\left(J^{\prime}\right)$, the minimum $p_{i j}$ represents the positive ideal solution, i.e., the alternative that minimises cost for each criterion and the maximum $\mathrm{p}_{\mathrm{ij}}$ represents the negative ideal solution, i.e., the alternative that maximises cost for each criterion.

5. Calculation of each alternative's geometric distance from the ideal solutions (Step 4):

$$
\begin{aligned}
& S_{i}^{+}=\sqrt{\sum_{j=1}^{n}\left(p_{i j}-p_{j}^{+}\right)^{2}} \\
& S_{i}^{-}=\sqrt{\sum_{j=1}^{n}\left(p_{i j}-p_{j}^{-}\right)^{2}}
\end{aligned}
$$


6. Calculation of the relative closeness $\mathrm{D}_{\mathrm{i}}$ to the ideal solution for each $\mathrm{A}_{\mathrm{i}}$ :

$$
D_{i}=\frac{S_{i}^{-}}{S_{i}^{+}+S_{i}^{-}}
$$

The presented framework incorporates the utilisation of TOPSIS multiple times in two discrete steps, as follows:

Step 1: TOPSIS is used several times, in accordance with the number of the engaged stakeholders (1), each time taking into consideration the preferences of a specific stakeholder (DM) thus ending up in providing an individual ranking for each one of them, which will eventually be unified in a new decision matrix (NDM):

$$
\mathrm{NDM}=\begin{array}{ccccc} 
& \mathrm{DM}_{1} & \mathrm{DM}_{2} & \ldots & \mathrm{DM}_{1} \\
\mathrm{~A}_{1} & \mathrm{e}_{11^{\prime}} & \mathrm{e}_{12}{ }^{\prime} & \ldots & \mathrm{e}_{11}{ }^{\prime} \\
\mathrm{A}_{2} & \mathrm{e}_{21}{ }^{\prime} & \mathrm{e}_{22}{ }^{\prime} & \ldots & \mathrm{e}_{21}{ }^{\prime} \\
\ldots & \ldots & \ldots & \ldots & \ldots \\
\mathrm{A}_{\mathrm{m}} & \mathrm{e}_{\mathrm{m} 1^{\prime}} & \mathrm{e}_{\mathrm{m} 2^{\prime}} & \ldots & \mathrm{e}_{\mathrm{ml}}{ }^{\prime} \\
\hline
\end{array}
$$

In case there have been attributed weights to the engaged stakeholders, then the weighted new decision matrix (WNDM) can be eventually calculated:

$$
\mathrm{WNDM}=\begin{array}{ccccc|}
\hline \multicolumn{1}{c}{\mathrm{DM}_{1}} & \mathrm{DM}_{2} & \ldots & \mathrm{DM}_{1} \\
\mathrm{~A}_{1} & \mathrm{we}_{1} * \mathrm{e}_{11^{\prime}} & \mathrm{we}_{2} * \mathrm{e}_{12}{ }^{\prime} & \ldots & \mathrm{we}_{1} * \mathrm{e}_{11^{\prime}} \\
\mathrm{A}_{2} & \mathrm{we}_{1} * \mathrm{e}_{21^{\prime}} & \mathrm{we}_{2} * \mathrm{e}_{22}{ }^{\prime} & \ldots & \mathrm{we}_{1} * \mathrm{e}_{2 l^{\prime}} \\
\ldots & \ldots & \ldots & \ldots & \ldots \\
\mathrm{A}_{\mathrm{m}} & \mathrm{we}_{1} * \mathrm{e}_{\mathrm{m} 1^{\prime}} & \mathrm{we}_{2} * \mathrm{e}_{\mathrm{m} 2^{\prime}} & \ldots & \mathrm{we}_{1} * \mathrm{e}_{\mathrm{ml}}{ }^{\prime} \\
\hline
\end{array}
$$

where $w_{k}, k=1,2, \ldots, 1$ stand for the weight of each stakeholder.

Step 2: TOPSIS is then used again for assembling the assessments of the WNDM (Step 1) under a common global model and analyse it towards reaching a final ranking [102].

The original TOPSIS framework is designed to provide results based on numerical input data, although specific stakeholders may appear more eager to provide their assessments using linguistic expressions, which are perceived to be the closest to the way humans express their ideas [103,104]. Therefore, we need to allow the option of providing input in comprehensible, easy-to-digest linguistic terms, which can be broadly found in the literature and are established often in association with a slightly diversified TOPSIS-based linguistic-driven approach [105]. Before proceeding to a multi-criteria analysis, we have to ensure consistency among the input data, which leaves no other option but to transform the initial data into a pre-defined numerical scale. To do so, the analyst, in cooperation with the group of stakeholders, may come up with a specific numerical scale and a respective linguistic one, where each linguistic term is matched with a discrete number of the numerical scale, thus enabling each stakeholder to provide their evaluations in either of the two. Eventually, the final input ends up being of numerical nature.

\section{Model Implementation in Selected European Countries}

\subsection{Stakeholder Input}

Energy poverty is caused by the interplay of three main factors, namely (a) low incomes; (b) high energy needs (especially in inefficient housing); (c) high energy prices. Although each of these factors is distinct, there is clear overlap and interplay amongst them. In addition, there is a diverse set of other causal factors that illustrate the regional, structural, economic and social specificities, such as climatic 
variation, fuel availability, stock type and performance, tenure, high living costs, etc., and may impose a large bearing on energy poverty.

Taking into consideration the numerous socioeconomic, legislative and institutional factors associated with a country's ability to deal with energy poverty, a diverse group of fifteen stakeholders were interviewed in order to elicit their knowledge; in the end, eleven such factors were considered and classified in eight major categories, acting as the evaluation criteria in the MCDA problem that follows. The engaged stakeholder group comprised eight utility representatives, one policy analyst, three energy efficiency experts and three researchers. The stakeholder engagement process is broken down into two discrete rounds: one round of detailed discussions on the topic of assembling the identified risks, and a second round featuring semi-structured questionnaires for the purposes of carrying out the multi-criteria analysis, where stakeholders were asked to assess the impact of the identified criteria on the potential of each country to deal with energy poverty.

The identification of the evaluation criteria was based on the context-specific information presented in Section 2 (Table 1) and was extended one step further by the stakeholder group, ending up in a thematic classification including the following categories: climate, demographics, economy, policy, residential building stock, energy market, obligation schemes and legislation (Table 2). The list of evaluation criteria is not exhaustive, given the multiplicity of the various factors that are directly or indirectly related to the problem of energy poverty, but was considered by stakeholders to be quite representative.

- Climate (quantitative): Reflects the impact of the climatic conditions in the problem of energy poverty and appears to be of medium importance according to the stakeholders' perspectives. It is a quantitative criterion of cost nature, quantified in terms of average winter-summer temperatures. It is perceived that the more extreme temperatures that prevail in each of the implicated countries, the larger the number of people who suffer from energy poverty, since the heating and cooling needs of a household during the winter and summer periods, respectively, are expected to be significantly higher, compared to countries with more mild climates.

- Demographics (quantitative): Measures the impact of the current country-specific demographic conditions in the resilience against energy poverty. This criterion is narrowed down to tracking the population growth of each country deriving straight from migratory flows, and it is treated as being of low significance among the stakeholders, although without that negating its existence, especially if we reckon in the prevailing conditions at the European and global levels, regarding the immigration problem. It implies cost features, since the engaged stakeholders have shown excessive consensus in that the more the migrants that settle in a country, the stronger the aggravation of the problem, given the predominantly low-quality of life of migrants.

- Economy (quantitative): Given its close interconnection with energy poverty, this specific criterion and its sub-components are expected to play a key role in the attempt to provide an integrated framework for assessing the resilience of several EU countries against energy poverty. This criterion is interpreted as the complementarity between two indicators, unequally important, drawing from the captured stakeholder assessments: The highly significant progress of unemployment rate, where it is highlighted that energy poverty is far more obvious in countries with increased shares of unemployment (cost nature); and the less important purchasing power of the citizens, which constitutes an indirect income measure, with stakeholders converging to the conclusion that a household is less prone to energy poverty if its purchasing power is located above the national average (benefit nature).

- Policy (qualitative): The impact of policy-making processes on hindering the rapid spread of energy poverty across the EU is of a positive nature, and it is approached qualitatively through the level of political will that the governments, local authorities and all relevant stakeholders show in legislating policies and designing schemes to effectively address the problem and its side effects. Given that energy poverty is not within the first priorities of the elected governments, regardless of their place in the chain of command (local, regional, national), political will is 
considered a criterion of high importance, closely associated with the lack of long-term energy strategy for targeting the grassroots of the problem, as well as the bureaucratic complexity of the regulatory framework.

- Residential building stock (quantitative): This criterion is quantified and evaluated based on three discrete metrics, all of which are linked to cost features: average building age, persons per room and number of tenants. According to the stakeholders' point of view, these metrics adequately represent the effect that the building stock has on energy poverty, with their significance in terms of influence on the problem spanning from extreme to low. It is noteworthy that building age seems to draw most of the attention, in that the greater the age of building, the more increased the chance of the shell failing to meet thermal standards, and thus sinking deep regarding its ability to maintain the thermal comfort of its holders.

- Energy market (quantitative): It is quantified in terms of electricity price and constitutes a criterion of negative nature as to its impact on energy poverty mitigation. It should be noted that high electricity prices do not necessarily lead to energy poverty, in the same way that low electricity prices do not constitute an effective way of dealing with the problem, since there are a multitude of parameters, including, among others, the age of building that should be examined jointly with electricity price trends in order to draw useful insights. However, high electricity price is a form of underlying energy poverty, in that increased fuel costs may provoke decreased energy consumption and thus a lack of thermal comfort for a household's holders, and thus it lies in the cluster of high-importance criteria.

- Obligation schemes (qualitative): The EED binds EU member states to introducing energy EEOSs which impose a legal obligation on member states to achieve new savings each year of $1.5 \%$ of the annual energy sales to final customers by volume. Article 7 creates space for member states to decide whether to stick with the EEOs or introduce alternative policy measures, as long as these measures deliver equivalent energy savings. In this respect, this qualitative criterion reflects the impact of an obligation scheme under Article 7 in the problem of energy poverty and it is considered to be of low importance in terms of benefit. The concept of examining the existence of $\mathrm{EEO}(\mathrm{s})$ under Article 7 is based on the stakeholders' broad consensus that an integrated design and development of a well-established scheme also motivates the enterprises of the private sector to engage, thus intensifying the efforts for developing the necessary tools to tackle energy poverty, while contributing to utilities serving their commitments.

- Legislation (qualitative): It is a qualitative criterion of benefit nature, focused on tracking down the existence of an official energy poverty definition among the examined countries. The establishment of a context-specific energy poverty definition does not straightforwardly imply lower levels of impact affection; however, it demonstrates a clear and coordinated attempt for a country to identify the problem and better target the ones affected, thus it is treated as extremely important. This statement appeared to gather much popularity among the stakeholders and, based on that reflection, the respective criterion is incorporated into the whole analysis.

The weights regarding the eleven evaluation criteria were unanimously assigned by the group of experts comprising the stakeholder team (Table 2). Eventually, the fifteen stakeholders participated in the process as equally weighted decision-makers.

In order for the stakeholders to evaluate the alternatives for countries against the abovementioned evaluation criteria, a five-term linguistic scale was used: None, Low, Medium, High, Extreme. An indicative example of a stakeholder's evaluations for all countries across the eleven criteria is presented in Figure 1. To ease readability of the following analysis, the implicated countries are graphically presented in light orange and labelled according to their two-letter abbreviation (Figure 2). 
Table 2. Evaluation criteria.

\begin{tabular}{cccc}
\hline & \multicolumn{2}{c}{ Evaluation Criteria } & Weights \\
\hline Climate & C1 & Average temperatures (winter-summer) & 2 \\
\hline Demographics & C2 & Population growth & 1 \\
\hline \multirow{2}{*}{ Economy } & C3 & Unemployment & 4 \\
& C4 & Purchasing power & 2 \\
\hline Policy & C5 & Political will & 3 \\
\hline \multirow{2}{*}{ Residential building stock } & C6 & Average building age & 4 \\
& C7 & Persons per room & 1 \\
\hline Energy market & C & Number of tenants & 2 \\
\hline Obligation schemes & C9 & Electricity price & 3 \\
\hline Legislation & C10 & Adoption of Article 7 & 1 \\
\hline
\end{tabular}

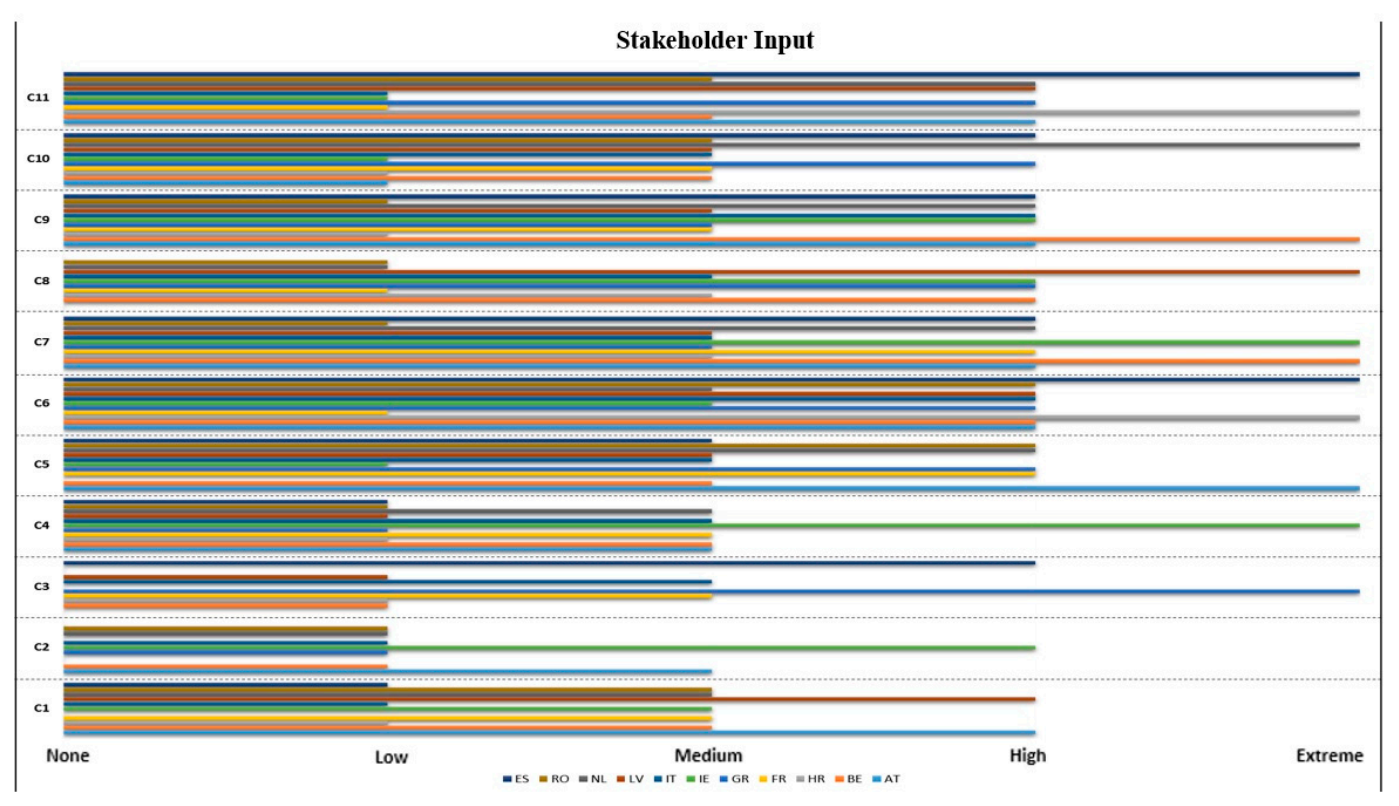

Figure 1. Indicative assessments regarding the criteria's level of impact on the potential of each country to deal with energy poverty. 


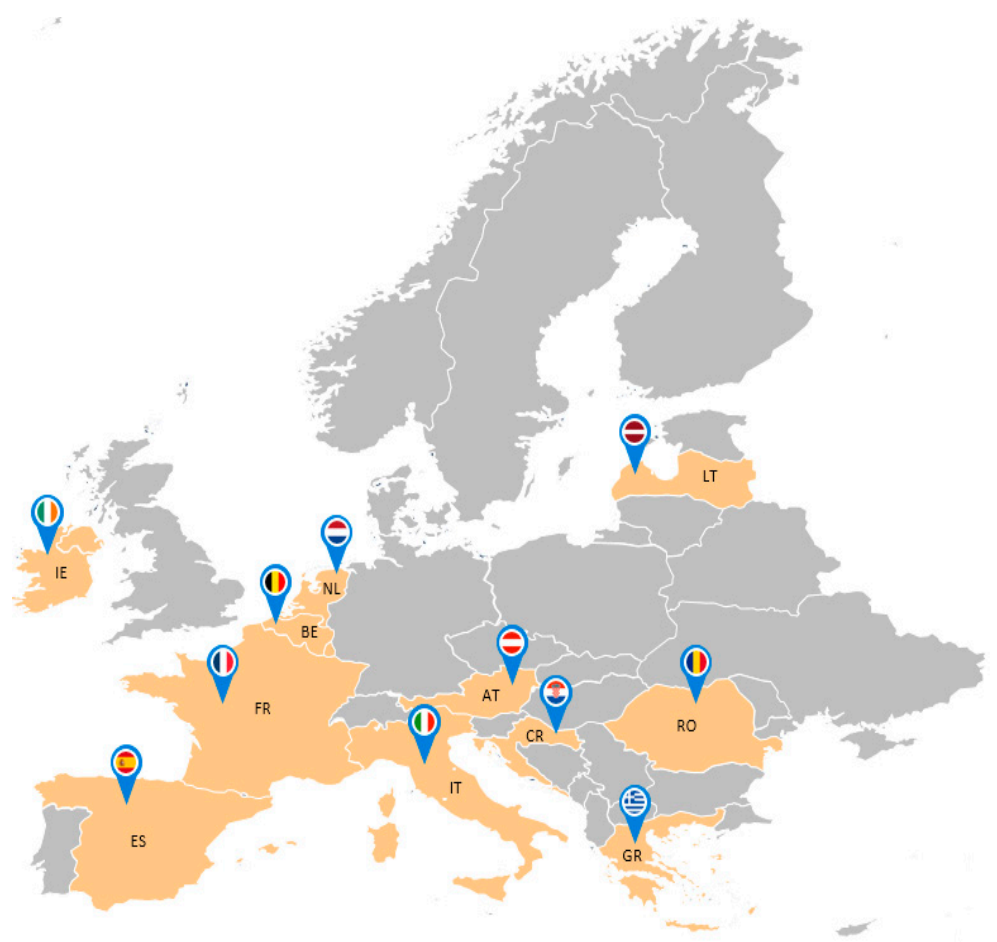

Figure 2. Graphical presentation of the examined countries.

\subsection{Multi-Criteria Analysis Results}

After capturing all the relevant information from the stakeholders, the elicited coherent qualitative narrative is fed into the multi-criteria model to produce quantitative results, in terms of calculating the final ranking for each country regarding their resilience against energy poverty through the use of the TOPSIS method.

Figure 3 summarises and graphically presents the results extracted from the application of the TOPSIS method to the eleven EU countries which are in the spotlight for the purposes of this paper. The countries are ranked in descending order according to their resilience to the ever-growing problem of energy poverty [106].

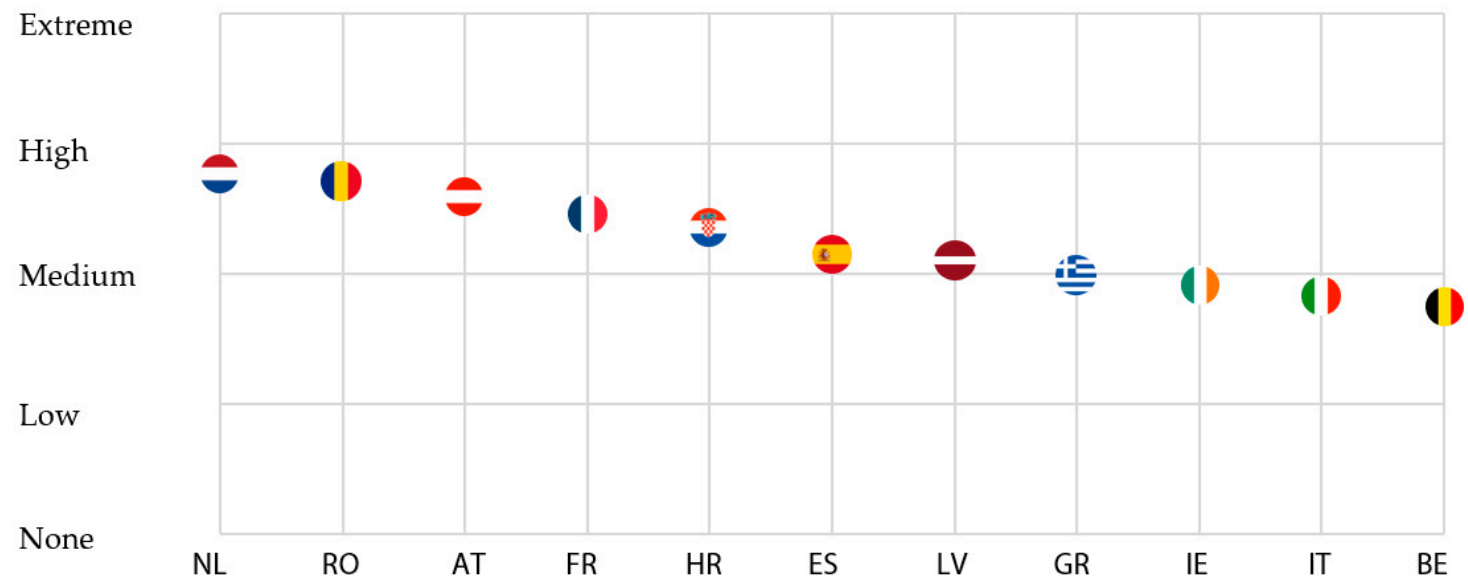

Figure 3. Final ranking of the examined countries in terms of resilience against energy poverty.

In this respect, the Netherlands is perceived to feature the highest potential for effectively dealing with the problem of energy poverty, with Austria and France also being among the first positions. It is noteworthy that Belgium, although constituting the central hub of the EU's political and economic 
developments, appears to hold the last position in the final ranking. Significant emphasis should also be laid on Romania, which-despite being a representative of the Southern cluster, which according to the literature review and the context described in Section 2 appears to suffer more from the problem-can be found in the second position. With regard to the rest of the Southern countries, they appear to display almost low resistance to energy poverty, with Italy possessing the worst possible position in the relative cluster. Last but not least, Ireland is placed as suffering the same fate as most of the Southern countries (Romania excepted), since it also lays deep in the final ranking.

Although some countries appear to stand out in terms of resilience, it is worth noting that the overall resilience seems to range around medium, more or less, without any country significantly overshadowing the rest. This comes as a clear confirmation of the findings of the literature review, which point out the still vague situation in Europe over the problem of energy poverty, which has raised a great deal of heated debate of late.

Evidently, all interviewed stakeholders agreed that there is a strict set of criteria among the examined ones which are considered the most critical to the analysis and expected to play a major role towards eliciting the final ranking (Table 2). These specific criteria are national unemployment rate, average building age and legislation. In other words, the group of stakeholders demonstrated high consensus regarding these three evaluation criteria as the main pillars which define to a great extent the resilience of each country against energy poverty. In this respect, a second qualitative MCDA analysis was implemented, also based on the TOPSIS method, drawing from the original stakeholders' evaluations but narrowed down to examining the three aforementioned criteria. The intention is to gain significant insights and draw useful comparisons between these two MCDA problems, eventually aiming to showcase the great importance of conceiving the detailed context for measuring the resilience of a country, on top of the most common factors that are linked to it.

Figure 4 presents the results extracted from the application of the TOPSIS method onto the $11 \mathrm{EU}$ countries with regard to the three criteria identified above (referred to as intermediate ranking hitherto), with a darkened mark of their national flag. To enhance clarity, an intermittent blue line was created to connect the flags indicating the intermediate ranking. The normal flags stand for the final ranking as obtained from the first MCDA problem, where the whole set of the initially identified criteria was taken into account.

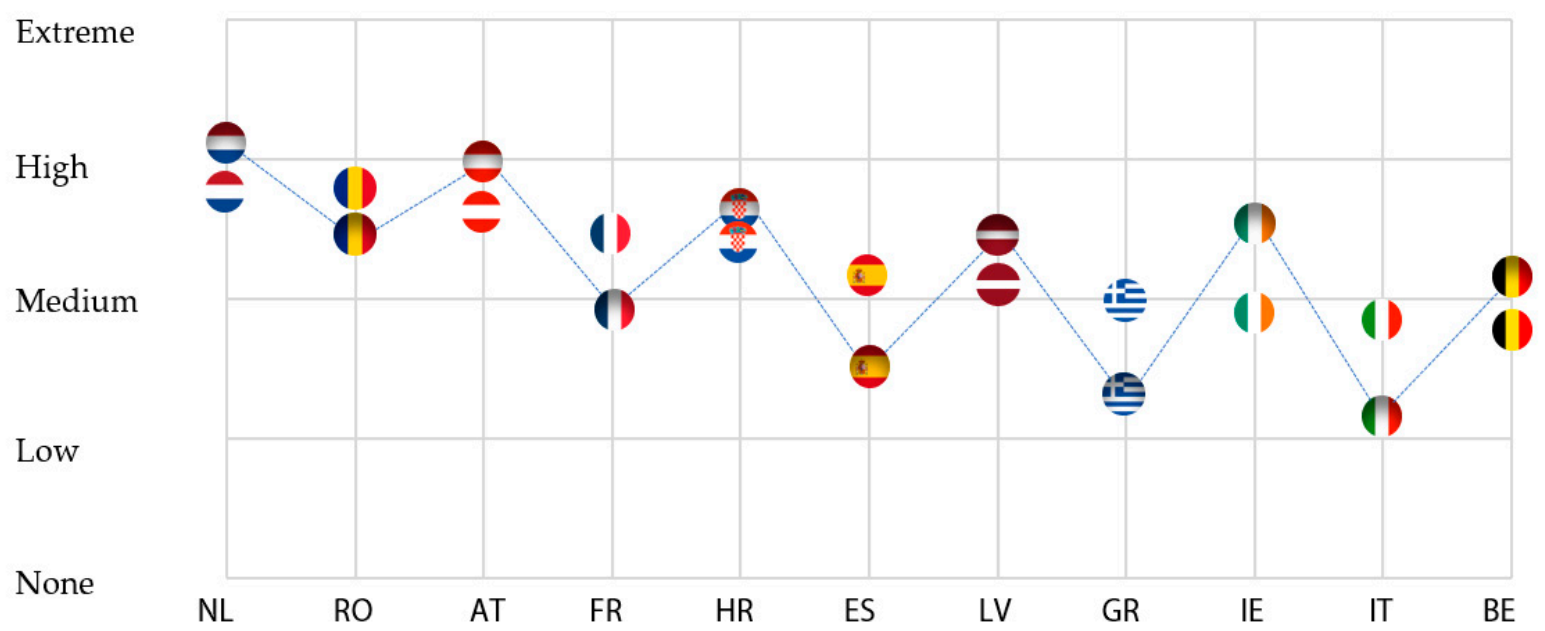

Figure 4. Intermediate ranking of the examined countries in terms of resilience against energy poverty according to the most important criteria.

In an attempt to interpret the results of Figure 4, the conclusions drawn are twofold. On the one hand, part of the Western and Northern countries seems to take a significant boost, but on the other hand, countries of the Southern cluster appear to lay deeper in the ranking. The most indicative examples of the former can be found in the cases of the Netherlands (which remains at the top of the 
relative ranking) and Belgium and Ireland, which both appear to have climbed towards the top of the relative ranking. However, if we take a closer look at the case of France, it can be noticed that, despite being included in the Western cluster, it has dropped by some places. With regard to the Southern countries, typical examples of the negative impact that the three examined criteria have upon them can be found in Greece, Italy, and Spain, which seem to drop down in the lower half of the ranking.

\section{Discussion}

Energy poverty affects 50 million people in the European Union according to the latest survey data [107], although this figure could be much higher given the limitations of the existing data sources. Based on that reflection, delving into the energy and socio-economic aspects of the phenomenon and capturing the different contexts in representative countries spanning across the EU emerge as a core activity in the pursuit of mitigating the effects of energy poverty. The results of the analysis, coupling stakeholder knowledge and a MCDA framework to provide the final ranking, showcase the acuteness of the problem in the EU region. However, when the discussion revolves around the accuracy of the results and the consistency of the proposed framework, we have to compare our findings to the ones drawn by the application of the most common indicators used in the literature for measuring the problem, given the significant lack of such relevant studies. At this point, it should be noted that a straight comparison between the two cannot be carried out due to the fact that EPOV provides several indicators for approaching the problem in a predominantly indirect way, while our analysis attempted to calculate in a direct way a total resilience value for each country against energy poverty.

Drawing from Figure 3, stakeholders seem to be in great alignment with the results stemming from the analysis of the most common EU indicators measuring energy poverty (e.g., arrears on utility bills, inability to keep home adequately warm during the winter, etc.), which indicate that countries spanning primarily across Central and Western Europe are perceived to suffer less from energy poverty, thus outranking the European South. To specify, according to data retrieved from EPOV for primary measuring indicators, Greece, Croatia and Latvia featured some of the highest rates of arrears on energy bills in 2018, with $35.6 \%, 17.5 \%$ and $11.6 \%$ of population, respectively [107]. In the same direction, when the inability to keep home adequately warm is put to the test, the European South can be found again among the first places, with representatives from Greece, Italy and Spain demonstrating great weakness in maintaining thermal comfort in their households $(22.7 \%, 14.1 \%$ and $9.1 \%$, respectively). Regarding this specific indicator, countries mainly located in Northern and Western Europe demonstrate significantly lower levels, with Austria, the Netherlands and France holding the primacy with $1.6 \%, 2.2 \%$ and $5 \%$, respectively.

Taking the above into consideration, our results confirm that energy poverty is a multi-faceted problem, deeply affected by a diverse set of factors, with the age of the building stock, household income per capita and fuel prices (i.e., electricity and natural gas) being among the most critical ones. They also highlight that, despite the profound lack of in-depth and accurate data to set the context-specific socio-economic conditions on a numerical basis, in order to facilitate the process of gaining useful insights for each country, the phenomenon can be appropriately approached, although additional and, more importantly, updated information (e.g., EPOV indicators) can provide significant added value to the accuracy of the current analysis. Finally, the results demonstrate that drawing strict conclusions based on a common set of indicators is an inappropriate strategy, as there are a multitude of factors that significantly deviate from country to country and thus should also be stress-tested and examined jointly with the ones that the current literature indicates.

Although the proposed framework constitutes a first step in our attempt to develop an effective and easy-to-use tool for measuring the resilience of different EU countries against energy poverty, there are also some key issues deriving for further investigation in the future, building on the results presented here. To begin with, the initial evaluations of each country against each criterion is largely dependent on the engaged stakeholder knowledge, thus implying nuggets of subjectivity. The latter should be pinpointed in order to highlight the importance of a more broadened set of EU stakeholders 
to join the procedure so as to increase the considered points of view and reduce possible bias, thus eventually ending up in developing integrated energy poverty resilience mechanisms. Furthermore, the weights of the evaluation criteria presented in Table 1 were derived as a result of several discussion rounds among the stakeholder group until a pre-defined and internally-agreed level of consensus was reached. Once the latter was met, the respective weights were extracted for use in the analysis. The main reason for ending up with a universal weighting vector to be used throughout the analysis was rooted in the authors' intention to shed light on the potential for assessing the resilience of several EU countries against energy poverty using a MCDA-based framework, rather than focusing on the MCDA process itself and increasing its complexity, as would have happened if each stakeholder had provided a unique weighting vector. However, the authors recognise the significant added value stemming from it as of major future perspective. Last but not least, the need for expanding the proposed analysis in order to incorporate all EU member states must be taken into account, as well as the set of evaluation criteria which must be composed of quantitative indicators in terms of providing their respective numerical values, rather than based on sole stakeholder knowledge.

Given the unprecedented challenges raised by the upheaval of the underlying economic recession, stakeholders' focus appears to have shifted towards filling the niches on the economic axis, thus making the presented framework a difficult task to be applied in many EU countries, despite the fact that it does display great potential, being a milestone towards reaching the final target.

\section{Conclusions}

The multiple causal factors and effects of energy poverty cross policy boundaries. The potential policy responses may reside in energy efficiency and carbon reduction policy, energy market regulation, social policy and wealth redistribution, economic and employment policy, housing standards and public health. Therefore, energy poverty is a complex concept that sits between economic, social and energy policy. However, if we reckon in the fuzziness of the regulatory and policy framework of the EU countries that have officially recognised and defined the problem, closely related to the instability of the European political scene, along with the ever-changing framework as a result of the continuous deficit-amending modifications, it becomes clear that the integrated assessment of a country's resilience against energy poverty, although emerging as a crucial factor in pursuit of mitigating the phenomenon, incorporates a multitude of prerequisites.

In this respect, the present study proposes a framework for efficiently assessing resilience against energy poverty based on accurate calculation with a finite number of easy-to-retrieve data. The framework's main implementation pillar lies in eliciting stakeholders' knowledge on the problem, calibrated by a set of context-specific socio-economic aspects, and employing a TOPSIS-based MCDA method for providing accurate results and valuable insights regarding the potential of several EU countries to deal with the problem of energy poverty. The usefulness of the framework is demonstrated in countries in both Southern/Eastern and Northern/Western Europe (Austria, Belgium, Croatia, France, Greece, Ireland, Italy, Latvia, the Netherlands, Romania, Spain), exploiting diversities and particularities associated with their context.

The results indicate that the proposed framework can serve as a novel alternative over traditional indicators and subjective peer-to-peer surveys which have been conducted throughout the years to address the problem. It should not be disregarded that the proposed methodology also incorporates elements of subjectivity, since it is based on the personal evaluations of a group of stakeholders. However, it is shown that it has led to comparable results to these of past studies and indirect indicators implying energy poverty, despite the inability of these previous approaches to delve into the problem as a whole, but rather in piecemeal ways. Last but not least, our findings confirm that energy poverty is a multi-dimensional problem, and thus drawing strict conclusions based on partial indicators and theoretical approaches is an inappropriate strategy for addressing the roots of the problem. 
Author Contributions: A.A.: Conceptualisation, Methodology, Software, Formal analysis, Writing-Original draft, Writing-Review and editing, Project administration; V.M.: Methodology, Formal analysis, Writing-Original draft, Writing-Review and editing; K.K.: Writing-Original draft; A.S.: Supervision, Writing-Review and editing, Project administration; J.P.: Supervision, Conceptualisation, Writing-Original draft, Writing-Review and editing, Project administration. All authors have read and agreed to the published version of the manuscript.

Funding: This research was funded by the European Union Horizon 2020 Research and Innovation Programme under grant agreement $\mathrm{n}^{\circ} 845905$ and the APC was funded by SocialWatt through the Institute of Communication and Computer Systems.

Acknowledgments: Part of the work presented is based on research conducted within the framework of SocialWatt, a project funded from the European Union Horizon 2020 Research and Innovation Programme under grant agreement $n^{\circ} 845905$. In this respect, the author team would like to pay tribute to the Consortium partners for providing detailed data that facilitated the integration of the examined contexts, and especially to Louise Sunderland from the Regulatory Assistance Project for gathering together all the necessary information that eventually contributed to conceiving the proposed methodology and framework presented. The sole responsibility for the content of this paper lies with the authors and does not necessarily reflect the opinion of the European Union.

Conflicts of Interest: The authors declare no conflict of interest.

\section{Abbreviations}

$\begin{array}{ll}\text { EC } & \text { European Commission } \\ \text { EU } & \text { European Union } \\ \text { EED } & \begin{array}{l}\text { Energy efficiency directive } \\ \text { Energy efficiency obligation } \\ \text { EEOS }\end{array} \\ \text { schemes } \\ \text { EUOV } & \text { Gu Energy Poverty Observatory } \\ \text { GDP } & \text { Greenhouse gas } \\ \text { GHG } & \text { International Energy Agency } \\ \text { IEA } & \text { Multi-criteria decision analysis } \\ \text { MCDA } & \text { New decision matrix } \\ \text { NDM } & \text { National energy and climate plan } \\ \text { NECP } & \text { Technique for Order of Preference } \\ \text { TOPSIS } & \text { by Similarity to Ideal Solution } \\ \text { WNDM } & \text { Weighted new decision matrix }\end{array}$

\section{References}

1. European Commission. Available online: https://ec.europa.eu/transparency/regdoc/rep/1/2019/EN/COM2019-175-F1-EN-MAIN-PART-1.PDF (accessed on 15 February 2020).

2. Doukas, H.; Nikas, A. Decision support models in climate policy. Eur. J. Oper. Res. 2020, 280, 1-24. [CrossRef]

3. Doukas, H.; Nikas, A.; Gonzalez-Eguino, M.; Arto, I.; Anger-Kraavi, A. From integrated to integrative: Delivering on the paris agreement. Sustainability 2018, 10, 2299. [CrossRef]

4. Nikas, A.; Doukas, H.; Martinez, L. A group decision making tool for assessing climate policy risks against multiple criteria. Heliyon 2018, 4, e00588. [CrossRef] [PubMed]

5. Forouli, A.; Doukas, H.; Nikas, A.; Sampedro, J.; Van De Ven, D.-J. Identifying optimal technological portfolios for European power generation towards climate change mitigation: A robust portfolio analysis approach. Util. Policy 2019, 57, 33-42. [CrossRef]

6. Papapostolou, A.; Karakosta, C.; Kourti, K.-A.; Doukas, H.; Psarras, J. Supporting Europe's energy policy towards a decarbonised energy system: A comparative assessment. Sustainability 2019, 11, 4010. [CrossRef]

7. Bouzarovski, S. Energy Poverty: (Dis) Assembling Europe's Infrastructural Divide; Palgrave Macmillan: Cham, Switzerland, 2018.

8. Access to Energy. Available online: https://ourworldindata.org/energy-access (accessed on 17 April 2020).

9. Spiliotis, E.; Arsenopoulos, A.; Kanellou, E.; Psarras, J.; Kontogiorgos, P. A multi-sourced data based framework for assisting utilities identify energy poor households: A case-study in Greece. Energy Sources Part B Econ. Plan. Policy 2020, 1-23. [CrossRef] 
10. Thomson, H.; Snell, C.; Bouzarovski, S. Health, well-being and energy poverty in Europe: A comparative study of 32 European countries. Int. J. Environ. Res. Public Health 2017, 14, 584. [CrossRef]

11. Indicators and Data. Available online: https://www.energypoverty.eu/indicators-data (accessed on 15 April 2020).

12. Household Composition Statistics. Available online: https://ec.europa.eu/eurostat/statistics-explained/index. php/Household_composition_statistics\#Household_size (accessed on 17 April 2020).

13. Bouzarovski, S.; Petrova, S. A global perspective on domestic energy deprivation: Overcoming the energy poverty-fuel poverty binary. Energy Res. Soc. Sci. 2015, 10, 31-40. [CrossRef]

14. Kolokotsa, D.; Santamouris, M. Review of the indoor environmental quality and energy consumption studies for low income households in Europe. Sci. Total. Environ. 2015, 536, 316-330. [CrossRef] [PubMed]

15. European Energy Poverty Index. Available online: https://www.openexp.eu/sites/default/files/publication/ files/european_energy_poverty_index-eepi_en.pdf (accessed on 5 April 2020).

16. Directive 2003/54/EC of the European Parliament. Available online: https://eur-lex.europa.eu/legal-content/ EN/TXT/?uri=CELEX\%3A32003L0054 (accessed on 10 April 2020).

17. Directive 2003/55/EC of the European Parliament. Available online: https://eur-lex.europa.eu/legal-content/ EN/TXT/?uri=CELEX\%3A32003L0055 (accessed on 10 April 2020).

18. Directive 2009/72/EC of the European Parliament. Available online: https://eur-lex.europa.eu/legal-content/ EN/ALL/?uri=celex\%3A32009L0072 (accessed on 10 April 2020).

19. Directive 2009/73/EC of the European Parliament. Available online: https://eur-lex.europa.eu/legal-content/ EN/ALL/?uri=CELEX\%3A32009L0073 (accessed on 10 April 2020).

20. Ringel, M.; Knodt, M. The governance of the European Energy Union: Efficiency, effectiveness and acceptance of the winter package 2016. Energy Policy 2018, 112, 209-220. [CrossRef]

21. Dobbins, A.; Nerini, F.F.; Deane, P.; Pye, S. Strengthening the EU response to energy poverty. Nat. Energy 2019, 4, 2-5. [CrossRef]

22. Bouzarovski, S.; Thomson, H. Transforming Energy Poverty Policies in the European Union: Second Annual Report of the European Union. Available online: https://www.energypoverty.eu/sites/default/files/ downloads/observatory-documents/20-01/epov_pan-eu_report_2019_final.pdf (accessed on 1 May 2020).

23. Geels, F.W.; Kern, F.; Fuchs, G.; Hinderer, N.; Kungl, G.; Mylan, J.; Neukirch, M.; Wassermann, S. The enactment of socio-technical transition pathways: A reformulated typology and a comparative multi-level analysis of the German and UK low-carbon electricity transitions (1990-2014). Res. Policy 2016, 45, 896-913. [CrossRef]

24. Lakatos, E.; Arsenopoulos, A. Investigating EU financial instruments to tackle energy poverty in households: A SWOT analysis. Energy Sources Part B Econ. Plan. Policy 2019, 14, 235-253. [CrossRef]

25. Streimikiene, D.; Balezentis, T. Innovative policy schemes to promote renovation of multi-flat residential buildings and address the problems of energy poverty of aging societies in former socialist countries. Sustainability 2019, 11, 2015. [CrossRef]

26. Luetzenburg, G.; Bittner, M.J.; Calsamiglia, A.; Renschler, C.; Bertos, J.E.; Poeppl, R.E. Climate and land use change effects on soil erosion in two small agricultural catchment systems Fugnitz-Austria, Can Revull-Spain. Sci. Total. Environ. 2020, 704, 135389. [CrossRef] [PubMed]

27. Mitter, H.; Schmid, E. Computing the economic value of climate information for water stress management exemplified by crop production in Austria. Agric. Water Manag. 2019, 221, 430-448. [CrossRef]

28. Bevölkerung. Available online: http://www.statistik.at/web_de/statistiken/menschen_und_gesellschaft/ bevoelkerung/index.html (accessed on 1 May 2020).

29. Van Mechelen, C.; Dutoit, T.; Hermy, M. Vegetation development on different extensive green roof types in a Mediterranean and temperate maritime climate. Ecol. Eng. 2015, 82, 571-582. [CrossRef]

30. Puschmann, P.; Sundin, E.; De Coninck, D.; d'Haenens, L. Migration and integration policy in Europe: Comparing Belgium and Sweden. In Images of Immigrants and Refugees in Western Europe: Media Representations, Public Opinion and Refugees' Experiences; d'Haenens, L., Joris, W., Heinderyckx, F., Eds.; Leuven University Press: Leuven, Belgium, 2019; pp. 213-216.

31. Demographic Balances and Indicators by Type of Projection. Available online: https://appsso.eurostat.ec. europa.eu/nui/show.do?dataset=proj_18ndbi\&lang=en (accessed on 1 May 2020).

32. Alexander, D.; Al-Khatib, J.A.; Al-Habib, M.I.; Bogari, N.; Salamah, N. Business culture's influence on negotiators' ethical ideologies and judgment: An eight-country study. J. Mark. Theory Pr. 2019, 27, 312-330. [CrossRef] 
33. Paoli, L.; Visschers, J.; Verstraete, C. The impact of cybercrime on businesses: A novel conceptual framework and its application to Belgium. Contemp. Cris. 2018, 70, 397-420. [CrossRef]

34. Furlani, S.; Cucchi, F.; Forti, F.; Rossi, A. Comparison between coastal and inland Karst limestone lowering rates in the northeastern Adriatic Region (Italy and Croatia). Geomorphology 2009, 104, 73-81. [CrossRef]

35. Đokić, I.; Fröhlich, Z.; Bakarić, I.R. The impact of the economic crisis on regional disparities in Croatia. Camb. J. Reg. Econ. Soc. 2015, 9, 179-195. [CrossRef]

36. Van Hoof, J.; Hensen, J.L. Quantifying the relevance of adaptive thermal comfort models in moderate thermal climate zones. Build. Environ. 2007, 42, 156-170. [CrossRef]

37. Population on 1st January by Age, Sex and Type of Projection. Available online: https://appsso.eurostat.ec. europa.eu/nui/show.do?dataset=proj_18np\&lang=en (accessed on 25 April 2020).

38. Real GDP Growth Rate-Volume. Available online: https://ec.europa.eu/eurostat/databrowser/view/tec00115/ default/table?lang=en (accessed on 25 April 2020).

39. Kaplanoglou, G.; Rapanos, V.T. Evolutions in consumption inequality and poverty in Greece: The impact of the crisis and austerity policies. Rev. Income Wealth 2016, 64, 105-126. [CrossRef]

40. Employment Rate by Sex. Available online: https:/ec.europa.eu/eurostat/databrowser/view/tesem010/ default/table?lang=en (accessed on 25 April 2020).

41. Papadopoulou, S.-D.; Kalaitzoglou, N.; Psarra, M.; Lefkeli, S.; Karasmanaki, E.; Georgios, T. Addressing energy poverty through transitioning to a carbon-free environment. Sustainability 2019, 11, 2634. [CrossRef]

42. Feeley, H.; Baars, J.-R.; Kelly-Quinn, M. The life history of Perla bipunctata Pictet, 1833 (Plecoptera: Perlidae) in the upper River Liffey, Ireland. Aquat. Insects 2009, 31, 261-270. [CrossRef]

43. Kitchin, R.; Hearne, R.; O'Callaghan, C. Housing in Ireland: From Crisis to Crisis. Available online: https://ssrn.com/abstract=2566297 (accessed on 2 May 2020).

44. Paoletti, E. Ozone and urban forests in Italy. Environ. Pollut. 2009, 157, 1506-1512. [CrossRef] [PubMed]

45. Campisano, A.; Gnecco, I.; Modica, C.; Palla, A. Designing domestic rainwater harvesting systems under different climatic regimes in Italy. Water Sci. Technol. 2013, 67, 2511-2518. [CrossRef]

46. Brandolini, A. The distribution of personal income in post-war Italy: Source description, data quality, and the time pattern of income inequality. G. Econ. Ann. Econ. 1999, 58, 183-239.

47. Matisons, R.; Brumelis, G. Influence of climate on tree-ring and earlywood vessel formation in Quercus robur in Latvia. Trees 2012, 26, 1251-1266. [CrossRef]

48. Skribane, I.; Jekabsone, S. Structural changes in the economy of Latvia after it joined the European Union. Intellect. Econ. 2013, 7, 29-41.

49. Mean and Median Income by Household Type-EU-SILC and ECHP Surveys. Available online: https: //appsso.eurostat.ec.europa.eu/nui/show.do?dataset=ilc_di04\&lang=en (accessed on 25 April 2020).

50. Taleghani, M.; Kleerekoper, L.; Tenpierika, M.; Dobbelsteen, A.V.D. Outdoor thermal comfort within five different urban forms in the Netherlands. Build. Environ. 2015, 83, 65-78. [CrossRef]

51. Teulings, C.N. House prices, land rents, and agglomeration benefits in the Netherlands. In International Housing Market Experience and Implications for China; Informa UK Limited: London, UK, 2019; pp. $62-87$.

52. Mihaela, S.; Bilan, Y.; Krajnakova, E.; Streimikiene, D.; Gędek, S. Renewable energy in the electricity sector and GDP per capita in the European Union. Energies 2019, 12, 2520. [CrossRef]

53. Paltineanu, C.; Chitu, E. Climate change impact on phenological stages of sweet and sour cherry trees in a continental climate environment. Sci. Hortic. 2020, 261, 109011. [CrossRef]

54. López, F.P.; Santiago, M.R.D.A. Sensitivity study of an opaque ventilated façade in the winter season in different climate zones in Spain. Renew. Energy 2015, 75, 524-533. [CrossRef]

55. Sanz-Hernández, A. Social engagement and socio-genesis of energy poverty as a problem in Spain. Energy Policy 2019, 124, 286-296. [CrossRef]

56. Singh, M.K.; Mahapatra, S.; Teller, J. An analysis on energy efficiency initiatives in the building stock of Liege, Belgium. Energy Policy 2013, 62, 729-741. [CrossRef]

57. Energy Consumption by End Use per Dwelling. 2016. Available online: https://www.eea.europa.eu/dataand-maps/daviz/energy-consumption-by-end-uses-3\#tab-chart_1 (accessed on 26 April 2020).

58. Energy Consumption in Households. Available online: https://ec.europa.eu/eurostat/statistics-explained/ index.php/Energy_consumption_in_households\#Energy_consumption_in_households_by_type_of_enduse (accessed on 26 April 2020). 
59. Mikulić, D.; Bakarić, I.R.; Slijepčević, S. The economic impact of energy saving retrofits of residential and public buildings in Croatia. Energy Policy 2016, 96, 630-644. [CrossRef]

60. Ć́osić, B.; Stanić, Z.; Duić, N. Geographic distribution of economic potential of agricultural and forest biomass residual for energy use: Case study Croatia. Energy 2011, 36, 2017-2028. [CrossRef]

61. Schneider, D.R.; Duić, N.; Bogdan, Ž. Mapping the potential for decentralized energy generation based on renewable energy sources in the Republic of Croatia. Energy 2007, 32, 1731-1744. [CrossRef]

62. Kulišić, B.; Radić, T.; Njavro, M. Agro-pruning for energy as a link between rural development and clean energy policies. Sustainability 2020, 12, 4240. [CrossRef]

63. EU Building Stock Observatory. Available online: https://ec.europa.eu/energy/en/topics/energy-efficiency/ energy-performance-of-buildings/eu-bso (accessed on 29 April 2020).

64. Energy Consumption by Residential Use. Available online: https://www.statistiques.developpementdurable.gouv.fr/consommation-denergie-par-usage-du-residentiel?rubrique=20\&dossier=168 (accessed on 29 April 2020).

65. Papadopoulos, A.M.; Oxizidis, S.; Papandritsas, G. Energy, economic and environmental performance of heating systems in Greek buildings. Energy Build. 2008, 40, 224-230. [CrossRef]

66. Census 2016 Summary Results Part 1. Available online: https://www.cso.ie/en/media/csoie/newsevents/ documents/census2016summaryresultspart1/Census2016SummaryPart1.pdf (accessed on 3 May 2020).

67. Energy in Ireland 2018 Report. Available online: https://www.seai.ie/publications/Energy-in-Ireland-2018.pdf (accessed on 3 May 2020).

68. Alberini, A.; Bigano, A. How effective are energy-efficiency incentive programs? Evidence from Italian homeowners. Energy Econ. 2015, 52, S76-S85. [CrossRef]

69. Siltumapgāde. Available online: https://www.em.gov.lv/lv/nozares_politika/energoefektivitate_un_ siltumapgade/siltumapgade/ (accessed on 3 May 2020).

70. Oxenaar, S.; Bosman, R. Managing the decline of fossil fuels in a fossil fuel intensive economy: The case of The Netherlands. In The Palgrave Handbook of Managing Fossil Fuels and Energy Transitions; Springer Science and Business Media LLC: Cham, Switzerland, 2019; pp. 139-165.

71. Namazkhan, M.; Albers, C.; Steg, L. A decision tree method for explaining household gas consumption: The role of building characteristics, socio-demographic variables, psychological factors and household behaviour. Renew. Sustain. Energy Rev. 2020, 119, 109542. [CrossRef]

72. Vidic, R.D.; Brantley, S.L.; Vandenbossche, J.M.; Yoxtheimer, D.; Abad, J.D. Impact of shale gas development on regional water quality. Science 2013, 340, 1235009. [CrossRef]

73. Akerboom, S.; Botzen, W.; Buijze, A.; Michels, A.; Van Rijswick, M. Meeting goals of sustainability policy: $\mathrm{CO} 2$ emission reduction, cost-effectiveness and societal acceptance. An analysis of the proposal to phase-out coal in the Netherlands. Energy Policy 2020, 138, 111210. [CrossRef]

74. Fondul de Locuinte 2018. Available online: http://www.insse.ro/cms/sites/default/files/field/publicatii/ fondul_de_locuinte_2018_1.pdf (accessed on 5 May 2020).

75. Housing Statistics. Available online: https://ec.europa.eu/eurostat/statistics-explained/index.php/Housing statistics (accessed on 26 April 2020).

76. Condiţiile de Viaţă ale Populaţiei din ROMÂNIA în Anul 2018. Available online: http://www.insse.ro/cms/ sites/default/files/field/publicatii/conditiile_de_viata_ale_populatiei_din_romania_in_anul_2018_0.pdf (accessed on 5 May 2020).

77. Balanta Energetica. Available online: http://www.insse.ro/cms/sites/default/files/field/publicatii/balanta energetica_si_structura_utilajului_energetic_in_anul_2018_0.pdf\#page=2\&zoom $=100,0,0$ (accessed on 7 May 2020).

78. Martín-Consuegra, F.; De Frutos, F.; Oteiza, I.; Agustín, H.A.; Aja, A.H. Use of cadastral data to assess urban scale building energy loss. Application to a deprived quarter in Madrid. Energy Build. 2018, 171, 50-63. [CrossRef]

79. Costa-Campi, M.T.; Jové-Llopis, E.; Trujillo-Baute, E. Energy poverty in Spain: An income approach analysis. Energy Sources Part B Econ. Plan. Policy 2019, 14, 327-340. [CrossRef]

80. Balances Energeticos. Available online: https://idae.es/estudios-informes-y-estadisticas (accessed on 5 May 2020). 
81. Energy Poverty in Austria. Available online: https://www.e-control.at/documents/1785851/1811597/ Energiearmut_Definitionen+und+Indikatoren_14082013_en.pdf/e91ed391-719f-469a-b16e-6f74703de96b? $\mathrm{t}=1438105557837$ (accessed on 8 May 2020).

82. The Energy Poverty Barometer (20092-015). Available online: https://www.kbs-frb.be/en/Virtual-Library/ 2015/20151123NT1 (accessed on 4 May 2020).

83. Lenz, N.V.; Grgurev, I. Energy poverty in Croatia: New Insights. In Proceedings of the 7th MAC, Prague, Czech Republic, 2016; Vopana, J., Douda, V., Kratochvil, R., Konecki, M., Eds.; MAC Prague Consulting Ltd.: Prague, Czech, 2016; pp. 2008-2012.

84. Tableau de Bord de la Préc Arité Énerg Étique. Available online: http://onpe.org/sites/default/files/tableaude-bord-juin2019.pdf (accessed on 10 May 2020).

85. Member State Report-Greece. Available online: https://www.energypoverty.eu/sites/default/files/downloads/ observatory-documents/19-06/member_state_report_-_greece.pdf (accessed on 3 May 2020).

86. Papada, L.; Kaliampakos, D. Measuring energy poverty in Greece. Energy Policy 2016, 94, 157-165. [CrossRef]

87. Bottom-up Analysis of Fuel Poverty in Ireland. Available online: https://www.dccae.gov.ie/documents/An\% 20Objective\%20Analysis\%20of\%20Energy\%20Poverty\%20in\%20Ireland.pdf (accessed on 3 May 2020).

88. Faiella, I.; Lavecchia, L. La povertà energetica in Italia. Politica Econ. 2015, 31, 27-76.

89. Fawcett, T.; Rosenow, J.; Bertoldi, P. Energy efficiency obligation schemes: Their future in the EU. Energy Effic. 2018, 12, 57-71. [CrossRef]

90. Nacionālais Enerǵētikas un Klimata Plāns. Available online: https://em.gov.lv/lv/nozares_politika/ nacionalais_energetikas_un_klimata_plans/ (accessed on 2 May 2020).

91. Van Middelkoop, M.; van Polen, S.; Holtkamp, R.; Bonnerman, F. Meten Met Twee Maten: Een Studie Naar de Betaalbaarheid van de Energierekening van Huishoudens. Available online: https:/www.pbl.nl/sites/default/ files/downloads/pbl-2018-de-betaalbaarheid-van-de-energierekening-van-huishoudens-3124.pdf (accessed on 4 May 2020).

92. Ascione, F.; Borrelli, M.; De Masi, R.F.; De Rossi, F.; Vanoli, G.P. A framework for NZEB design in Mediterranean climate: Design, building and set-up monitoring of a lab-small villa. Sol. Energy 2019, 184, 11-29. [CrossRef]

93. Sărăcia Energetică şi Consumatorul Vulnerabil; Evidenţe din România şi Europa. Available online: http: //democracycenter.ro/application/files/4515/1152/3672/raport_tehno.pdf (accessed on 6 May 2020).

94. Clodnitchi, R.; Buşu, C. Energy poverty in Romania-Drivers, effects and possible measures to reduce its effects and number of people affected. In Proceedings of the International Conference on Business Excellence; Walter de Gruyter GmbH: Berlin, Germany, 2017; Volume 11, pp. 138-145.

95. Estrategia Nacional Contra La Pobreza Energetica 20192-024. Available online: https://www.miteco.gob.es/es/ prensa/estrategianacionalcontralapobrezaenergetica2019-2024_tcm30-496282.pdf (accessed on 7 May 2020).

96. Yoon, K.; Hwang, C.-L. Multiple attribute decision making. Mult. Attrib. Decis. Mak. 1995, 104. [CrossRef]

97. Chen, C.-T. Extensions of the TOPSIS for group decision-making under fuzzy environment. Fuzzy Sets Syst. 2000, 114, 1-9. [CrossRef]

98. Chen, T.-Y.; Tsao, C.-Y. The interval-valued fuzzy TOPSIS method and experimental analysis. Fuzzy Sets Syst. 2008, 159, 1410-1428. [CrossRef]

99. Chen, S.-M.; Lee, L.-W. Fuzzy multiple attributes group decision-making based on the interval type-2 TOPSIS method. Expert Syst. Appl. 2010, 37, 2790-2798. [CrossRef]

100. Papapostolou, A.; Karakosta, C.; Apostolidis, G.; Doukas, H. An AHP-SWOT-Fuzzy TOPSIS approach for achieving a cross-border RES cooperation. Sustainability 2020, 12, 2886. [CrossRef]

101. Papapostolou, A.; Karakosta, C.; Doukas, H. Analysis of policy scenarios for achieving renewable energy sources targets: A fuzzy TOPSIS approach. Energy Environ. 2016, 28, 88-109. [CrossRef]

102. Krohling, R.A.; Campanharo, V.C. Fuzzy TOPSIS for group decision making: A case study for accidents with oil spill in the sea. Expert Syst. Appl. 2011, 38, 4190-4197. [CrossRef]

103. Agell, N.; Sánchez, M.; Prats, F.; Roselló, L. Ranking multi-attribute alternatives on the basis of linguistic labels in group decisions. Inf. Sci. 2012, 209, 49-60. [CrossRef]

104. Estrella, F.J.; Onar, S.C.; Rodríguez, R.M.; Oztaysi, B.; Martinez, L.; Kahraman, C. Selecting firms in University technoparks: A hesitant linguistic fuzzy TOPSIS model for heterogeneous contexts. J. Intell. Fuzzy Syst. 2017, 33, 1155-1172. [CrossRef] 
105. Herrera, F.; Martinez, L.; Sanchez, P.J. Managing non-homogeneous information in group decision making. Eur. J. Oper. Res. 2005, 166, 115-132. [CrossRef]

106. Neacsa, A.; Panait, M.; Muresan, J.D.; Voica, M.C. Energy poverty in European Union: Assessment difficulties, effects on the quality of life, mitigation measures. some evidences from Romania. Sustainability 2020, 12, 4036. [CrossRef]

107. Addressing Energy Poverty in the European Union: State of Play and Action. Available online: https://www.energypoverty.eu/sites/default/files/downloads/observatory-documents/19-06/ paneureport2018_updated2019.pdf (accessed on 15 May 2020).

(C) 2020 by the authors. Licensee MDPI, Basel, Switzerland. This article is an open access article distributed under the terms and conditions of the Creative Commons Attribution (CC BY) license (http://creativecommons.org/licenses/by/4.0/). 